\title{
KETIDAKEFEKTIFAN KALIMAT PADA RUBRIK BERITA UTAMA KORAN HARIAN PAGI RADAR SURABAYA EDISI JULI 2016
}

\author{
Amalia Rizqi Septiani, Rahayu Pujiastuti \\ (Pendidikan Bahasa dan Sastra Indonesia, FKIP, Universitas PGRI Adi Buana Surabaya) \\ amaliarizqi994@gmail.com, rahayu_pujiastuti30yahoo.co.id
}

\begin{abstract}
ABSTRAK
Menurut media, bahasa dapat dibedakan seperti bahasa lisan dan bahasa tulis. Salah satu bentuk bahasa tulis adalah surat kabar. Surat kabar memuat rubrik antara lain bagian berita utama, surat, editorial, dan lain sebagainya. Dalam penelitian ini, permasalahan dibatasi pada headline. Berita adalah informasi yang mempunyai nilai dan minat yang signifikan tentang suatu peristiwa yang disajikan oleh media massa seperti surat kabar, televisi, radio, dan lain-lain yang dipublikasikan secara luas. Bahasa yang tepat adalah bahasa yang baik dan benar agar pembaca mampu memahami pesan yang disampaikan pengarang. Kalimat efektif adalah kalimat yang mengungkapkan suatu gagasan atau konsep yang dikemukakan oleh pengarang sehingga pembaca dapat memahami dengan baik gagasan atau konsep tersebut dengan sempurna. Rumusan masalah yang digunakan dalam penelitian ini adalah "Bagaimana ketidakefektifan kalimat pada rubrik Berita Utama Harian Pagi Harian Radar Surabaya edisi Juli 2016?”. Tujuan dari penelitian ini adalah untuk mendeskripsikan ketidakefektifan kalimat pada rubrik Berita Utama Harian Pagi Harian Radar Surabaya Edisi Juli 2016. Penelitian ini menggunakan pendekatan kualitatif dengan metode deskriptif. Data penelitian berupa kalimat yang tidak efektif. Sumber data adalah bagian berita utama pada surat kabar Harian Pagi Radar Surabaya edisi Juli 2016. Teknik pengumpulan data menggunakan teknik dokumentasi. Teknik analisis data terdiri dari identifikasi, klasifikasi, pengkodean, interpretasi, dan penarikan kesimpulan. Berdasarkan hasil penelitian dan pembahasan, dapat disimpulkan bahwa ketidakefektifan kalimat pada bagian Pemberitaan Terpopuler Surat Kabar Harian Pagi Radar Surabaya edisi Juli 2016 disebabkan oleh ketidaksesuaian, ketidakselarasan, keragu-raguan, ketidaktepatan, ketidaktepatan, kurang runtut. , dan inkoherensi.
\end{abstract}

Kata Kunci: Kalimat Efektif, Surat Kabar, Berita

\section{PENDAHULUAN}

Bahasa memiliki peranan penting dalam kehidupan manusia. Melalui bahasa, manusia dapat saling berkomunikasi dengan lingkungan di sekitarnya.Menurut Ferdinand de Sausure (dalam Chaer, 2007:32), bahasa didefinisikan sebagai sistem lambang bunyi yang arbitrer yang digunakan oleh para anggota kelompok sosial untuk bekerjasama, berkomunikasi, dan mengidentifikasi diri.

Berdasarkan medianya, bahasa dapat dibagi menjadi bahasa lisan dan bahasa tulisan. Salah satu bentuk bahasa tulisan adalah koran. Menurut Sutarman (2009:25), koran adalah suatu media informasi yang berisi berita-berita terkini dengan berbagai topik. Topiknya ada yang bertema politik, olahraga, pendidikan, dan 
kejadian yang terbaru. Ada juga koran yang isinya dikembangkan untuk bidang tertentu, seperti bisnis, politik, atau olahraga. Secara umum, koran diterbitkan setiap hari, namun ada juga yang diterbitkan skala mingguan dan terbit tiap sore hari.

Koran harus menggunakan bahasa yang tepat. Bahasa yang tepat adalah bahasa yang baik dan benar agar pembaca mampu memahami pesan yang disampaikan oleh penulis. Menurut Satata (2012:105), penggunaan kaidah bahasa yang baik dalam berkomunikasi secara tertulis sangat penting. Artinya, dalam menulis penulis harus memperhatikan kalimat-kalimat yang ditulisnya sehingga orang yang membaca tulisan tersebut dapat memahami maksud yang disampaikan penulis. Penyampaian informasi ini harus pula ditunjang oleh pemakaian kalimat yang efektif.

Menurut Arifin (2010:97), kalimat efektif ialah kalimat yang mempunyai kemampuan untuk menimbulkan kembali gagasangagasan pada pikiran pendengar atau pembaca seperti apa yang ada dalam pikiran pembicara atau penulis. Arifin membagi ciri-ciri kalimat efektif menjadi tujuh yaitu kesepadanan struktur, keparalelan bentuk, ketegasan makna, kehematan kata, kecermatan kata, kepaduan gagasan, dan kelogisan bahasa.

Salah satu koran yang menarik bila ditinjau dari kalimat efektif adalah koran Harian Pagi Radar Surabaya. Koran Harian Pagi Radar Surabaya adalah surat kabar yang terbit di Surabaya, Jawa Timur. Harian ini termasuk dalam grup Jawa Pos serta memiliki sirkulasi yang terbatas di kawasan Surabaya dan sekitarnya. Sebagai perusahaan media cetak yang besar, seharusnya dalam menyampaikan informasi kepada pembaca, khususnya berita utama harus menggunakan bahasa baku. Akan tetapi, ketidakefektifan kalimat sering ditemukan di dalam berita utama koran Harian Pagi Radar Surabaya.

Berikut beberapa kutipan berita yang tidak menggunakan kalimat efektif.

1. Misalnya, seperti bendahara, pegintervaris barang atau operator komputer.

2. Pembangunan diarahkan untuk mendukung pembangunan daerah, memperluas lapangan kerja, dan perbaikan taraf hidup rakyat.

Contoh kalimat (1) dikatakan tidak efektif karena tidak memiliki ciri kehematan. Kalimat tersebut memiliki dua kata yang bersinonim yaitu kata misalnya dan seperti.

Contoh kalimat (2) dikatakan tidak efektif karena tidak memiliki ciri keparalelan atau kesejajaran. Kalimat tersebut tidak memiliki tiga bentuk kata yang tidak sejajar yaitu kata mendukung, memperluas, dan perbaikan.

Berdasarkan permasalahan tersebut, ditentukan pertanyaan penelitian "Bagaimana ketidakefektifan kalimat pada rubrik Berita Utama Koran Harian Pagi Radar Surabaya Edisi Juli 2016?"

Tujuan penelitian ini yaitu untuk mendeskripsikan ketidakefektifan kalimat pada rubrik Berita Utama Koran Harian Pagi Radar Surabaya Edisi Juli 2016.

Hasil penelitian ini diharapkan dapat memberikan manfaat, baik manfaat teoritis maupun manfaat praktis.Secara teoritis, manfaat penelitian ini dapat memperdalam khazanah ilmu pengetahuan yang berkaitan dengan penulisan kalimat efektif. Secara praktis, penelitian ini 
bermanfaatyaitu bagi pembaca, hasil penelitian ini dapat digunakan sebagai masukan para penulis agar lebih teliti dan cermat dalam menggunakan kalimat efektif khususnya dalam menulis berita. Bagi peneliti, dapat menjadi referensi bagi peneliti untuk mengembangkan teori-teori mengenai kalimat efektif. Bagi guru, dapat menjadi referensi bagi guru sebagai bahan pembelajaran Bahasa Indonesia.

\section{METODE PENELITIAN}

Pendekatan yang digunakan dalam penelitian ini adalah pendekatan kualitatif dengan metode deskriptif. Menurut Denzim dan Lincoln (dalam Moleong, 2010:5), penelitian kualitatif adalah penelitian yang menggunakan latar alamiah, dengan maksud menafsirkan fenomena yang terjadi dan dilakukan dengan jalan melibatkan berbagai metode yang ada.Data dalam penelitian ini berupa kalimat yang tidak efektif pada rubrik Berita Utama koran Harian Pagi Radar Surabaya edisi Juli 2016. Sumber data dalam penelitian ini adalah rubrik berita utama pada koran Harian Pagi Radar Surabaya edisi Juli 2016. Teknik pengumpulan data yang digunakan dalam penelitian ini adalah teknik dokumentasi. Penelitian ini menggunakan empat prosedur pengumpulan data yaitu mengumpulkan rubrik berita utama dalam koran Harian Pagi Radar Surabaya edisi Juli 2016; (2) membaca rubrik berita utama yang terkumpul untuk mengetahui ketidakefektifan kalimat; (3) mengidentifikasi kalimat-kalimat yang tidak efektif; dan (4) mengarsipkan kalimat-kalimat yang tidak efektif. Teknik Analisis data yang digunakan dalam penelitian ini adalah teknik deskriptif. Menurut Mahsun (2005:233), penelitian deskriptif dilakukan dengan cara mendiskripsikan kenyataan-kenyataan yang penulis temukan dalam lapangan. Langkah-langkah analisis data dalam penelitian ini yaitu (1) membaca kembali data yang telah dikumpulkan;

mengklasifikasikan kalimat-kalimat yang tidak efektif; (3) melakukan pengodean data dengan cara membuat singkatan atau kode pada kalimatkalimat yang tidak efektif; (4) menginterpretasikan data yang telah diperoleh untuk dianalisis berdasarkan teori yang digunakan; dan (5) menyimpulkan kalimatkalimat tidak efektif yang ada pada teks berita utama.

\section{HASIL DAN PEMBAHASAN \\ A. Hasil Penelitian}

Ketidakefektifan kalimat dalam penelitian ini menggunakan teori Arifin yang dilihat berdasarkan ciriciri kalimat efektif. Menurut Arifin (2010), terdapat tujuh ciri-ciri dalam kalimat efektif di antaranya kesepadanan struktur, keparalelan bentuk, ketegasan makna, kehematan kata, kecermatan kata, kepaduan gagasan, dan kelogisan bahasa.Berdasarkan analisis yang dilakukan, peneliti menemukan tujuh ciri-ciri kalimat efektif dalam Rubrik Berita Utama Koran Harian Pagi Radar Surabaya Edisi Juli 2016. Informasi mengenai ketidakefektifan kalimat sebagai berikut.

$\begin{array}{ll}\text { 1. Ketidakefektifan } & \text { karena } \\ \text { ketidaksepadanan } & \\ \text { Kesepadanan } & \text { adalah }\end{array}$ keseimbangan antara pikiran atau gagasan dengan struktur bahasa yang dipakai. Ciri-ciri kalimat yang memiliki kesepadanan struktur, yaitu kalimat harus memiliki subjek dan 
predikat yang jelas. Ketidakjelasan subjek dan predikat dalam kalimat dapat menjadikan kalimat itu tidak efektif. Hasil penelitian yang telah diperoleh penulis berdasarkan ciri ketidaksepadanan sebagai berikut.

\section{a. Karena bus mampu menampung} banyak orang dan lebih nyaman. (ANA.03/07/2016.Kpda)

Kalimat (a) dikatakan tidak efektif dari segi kesepadanan karena subjeknya tidak jelas. Subjek bus didahului oleh kata depan karena. Sebagai kata depan, kata karena tidak seharusnya diletakkan di depan subjek. Jika kata karena terletak di awal kalimat, maka kalimat tersebut hanya berisi keterangan. Hal ini hendaknya dihindarkan agar kesatuan gagasan yang hendak disampaikan penulis dapat dipahami dengan baik oleh pembaca. Dengan menggunakan dasar tersebut, seharusnya kalimat tersebut berbunyi Bus mampu menampung banyak orang dan lebih nyaman.

Pada judul berita utama yang lain juga ditemukan ketidakefektifan kalimat pada ciri kesepadanan. Berikut berita utama tersebut.

b. Di mana mudik adalah salah satu implementasi dari kembali.

(PKAGIKPDJ.04/07/2016.Kpd

a)

Kalimat (b) dikatakan tidak efektif dari segi kesepadanan karena subjeknya tidak jelas. Subjek mudik didahului oleh kata tanya di mana. Kata di mana adalah kata yang menanyakan tentang suatu arah atau tempat. Kata tanya biasanya diletakkan di awal kalimat dan diakhiri dengan tanda tanya. Pada kalimat tersebut, kata di mana memang terletak di awal kalimat.
Akan tetapi, tidak cocok dengan kesatuan gagasan dalam kalimat. Kalimat tersebut berisi tentang pengertian mudik dan bukanlah sebuah kalimat pertanyaan yang diakhiri dengan tanda tanya. Kalimat tersebut akan menjadi kalimat efektif jika kata di mana di depan subjek dihilangkan. Dengan menggunakan dasar tersebut, seharusnya kalimat (b) berbunyi Mudik adalah salah satu implementasi dari kembali.

2. Ketidakefektifan karena ketidakparalelan

Keparalelan adalah kesamaan bentuk kata yang digunakan dalam kalimat itu. Artinya kalau bentuk pertama menggunakan nomina, bentuk kedua dan seterusnya juga harus menggunakan nomina. Kalau bentuk pertama menggunakan verba, bentuk kedua juga mengggunakan verba. Hasil penelitian yang telah diperoleh penulis berdasarkan ciri ketidakparalelan sebagai berikut.

\section{c. Kami langsung bangunkan keluarga dan menyelamatkan diri dulu.}

\section{(DM148OKR.14/07/2016.Kpr)}

Kalimat (c) tidak mempunyai keparalelan karena dua bentuk kata yang menduduki predikat memiliki bentuk berbeda yaitu kata bangunkan dan menyelamatkan. Kata bangunkan tidak jelas akan dijadikan kata kerja aktif atau kata kerja pasif. Namun, pada predikat lainnya terdapat kata kerja aktif yaitu menyelamatkan. Kata bangunkan harus diubah menjadi membangunkan sehingga mempunyai kesejajaran dengan predikat lainnya. Dengan menggunakan dasar tersebut, seharusnya kalimat $\quad$ (c) berbunyi Kami langsung membangunkan 
keluarga dan menyelamatkan diri dulu.

3. Ketidakefektifan karena ketidaktegasan

Ketegasan atau penekanan adalah suatu perlakuan penonjolan pada ide pokok kalimat. Hasil penelitian yang telah diperoleh penulis berdasarkan ciri ketidaktegasan sebagai berikut.

d. Dengan kasus kanker serviks atau leher rahim dan payudara menempati urutan teratas.

(KKJMBMBKSSL.31/07/2016. Ktgs)

Kalimat (d) tidak efektif dari segi ketidaktegasan karena sebelum kata kasus kanker serviks atau leher rahim dan payudara terdapat kata dengan. Untuk memberi penekanan pada bagian tertentu, ide yang dipentingkan seharusnya diletakkan di bagian awal kalimat. Dalam kalimat di atas, ide yang dipentingkan adalah kasus kanker serviks atau leher rahim dan payudara. Dengan menggunakan dasar tersebut, seharusnya kalimat (d) berbunyi Kasus kanker serviks atau leher rahim dan payudara menempati urutan teratas.

Pada judul berita utama yang lain juga ditemukan ketidakefektifan kalimat pada ciri ketidaktegasan. Berikut berita utama tersebut.

e. Karena bus mampu menampung banyak orang dan lebih nyaman.

(ANA.03/07/2016.Ktgs)

Kalimat (e) tidak efektif dari segi ketidaktegasan karena sebelum kata bus terdapat kata karena. Untuk memberi penekanan pada bagian tertentu, ide yang dipentingkan seharusnya diletakkan di bagian awal kalimat. Dalam kalimat di atas, ide yang dipentingkan adalah bus. Dengan menggunakan dasar tersebut, seharusnya kalimat (e) berbunyi Bus mampu menampung banyak orang dan lebih nyaman.

4. Ketidakefektifan karena ketidakhematan

Kehematan dalam kalimat efektif adalah hemat mempergunakan kata, ungkapan, frasa yang dapat memperjelas kalimat. Hasil penelitian yang telah diperoleh penulis berdasarkan ciri ketidakhematan sebagai berikut.

f. Warga Basewarga Jalan Asahan KM 4 Kelurahan Dolok Mariawan, Kecamatan Siantar, Simalungun, Sumatera Utara ini lalu melaporkan kejadian yang menimpanya ini ke Polsek Trenggilis Mejoyo.

(KMDUPR10JA.01/07/2016.Ke h)

Kalimat (f) tidak efektif dari segi kehematan karena terdapat pengulangan unsur kata yang sama dalam satu kalimat yaitu kata ini. Penghematan dapat dilakukan dengan cara menghilangkan salah satu kata ini pada kalimat tersebut. Dengan menggunakan dasar tersebut, seharusnya kalimat (f) berbunyi Warga Basewarga Jalan Asahan KM 4 Kelurahan Dolok Mariawan, Kecamatan Siantar, Simalungun, Sumatera Utara ini lalu melaporkan kejadian yang menimpanya ke Polsek Trenggilis Mejoyo.

Pada judul berita utama yang lain juga ditemukan ketidakefektifan kalimat pada ciri ketidakhematan. Berikut berita utama tersebut. 


\section{g. Fenomena La Nina sendiri telah terjadi sejak bulan Maret lalu.(HATHS.24/07/2016. Keh)}

Kalimat (g) tidak efektif dari segi kehematan karena terdapat kata hiponim. Dalam bahasa, ada kata yang merupakan bawahan makna kata suatu ungkapan yang lebih tinggi. Kata Maret sudah mengandung makna bulan sehingga dapat dikatakan bahwa dalam makna kata tersebut terkandung makna dasar kelompok kata yang bersangkutan. Agar tidak terjadi pemborosan, kalimat tersebut dapat diperbaiki dengan cara menghilangkan kata bulan. Dengan menggunakan dasar tersebut, seharusnya kalimat berbunyi Fenomena La Nina sendiri telah terjadi sejak Maret lalu.

5. Ketidakefektifan karena ketidakcermatan

Kecermatan kalimat efektif adalah cermat dan tepat dalam memilih kata sehingga kalimat yang dihasilkan tidak rancu dan bermakna ganda. Hasil penelitian yang telah diperoleh penulis berdasarkan ciri ketidakcermatan sebagai berikut.

h. Begitu sudah saya ngirim lagi ke kecamatan, baru pemohon mengambil.

\section{(AR700JKDKP.05/07/2016. Kec)}

Kalimat (h) tidak efektif dari segi kecermatan karena kata ngirim merupakan kata yang tidak baku. Kata ngirim terpengaruh dari interferensi bahasa. Perbaikannya dapat dilakukan dengan mengubah menjadi bahasa yang baku agar dapat dipahami oleh pembaca. Kata ngirim harus diperbaiki dengan mengubahnya menjadi kata kerja aktif mengirim. Dengan menggunakan dasar tersebut, seharusnya kalimat (h) berbunyi Begitu sudah saya mengirim lagi ke kecamatan, baru pemohon mengambil.

6. Ketidakcermatan karena
ketidakpaduan

Kepaduan adalah kepaduan pernyataan dalam sebuah kalimat sehingga informasi yang disampaikan tidak terpecah-pecah. Hasil penelitian yang telah diperoleh penulis berdasarkan ciri ketidakpaduan sebagai berikut.

i. Dikatakan, Polda Jatim sudah mendapatkan informasi tentang hilangnya mahasiswa kedokteran Unair.(ZMFDR.27/07/2016.Kp du)

Kalimat (i) tidak efektif dari segi kepaduan. Menurut Arifin (2010:104), Kalimat yang padu tidak perlu menyisipkan kata tentang antara predikat kata kerja dan objek penderita. Agar tidak menimbulkan kalimat yang bertele-tele, kata tentang tersebut harus dihilangkan. Dengan menggunakan dasar tersebut, seharusnya kalimat (i) berbunyi Dikatakan, Polda Jatim sudah mendapatkan informasi hilangnya mahasiswa kedokteran Unair.

\section{Ketidakefektifan karena ketidaklogisan}

Kelogisan dalam kalimat efektif adalah ide kalimat dapat diterima oleh akal dan sesuai dengan kaidah EYD. Hasil penelitian yang telah diperoleh penulis berdasarkan ciri ketidaklogisan sebagai berikut.

\section{j. Dari sejak proses pembangunannya saja, gedung-}


gedung itu butuh pekerja yang tentunya didatangkan dari daerah lain.

\section{(300RPMS.10/07/2016.Klgs)}

Kalimat (j) tidak efektif dari segi kelogisan karena kalimat tersebut tidak logis jika gedung membutuhkan pekerja. Seharusnya, kata yang masuk akal dan sesuai adalah pemilik gedung. Karena bila dipikir secara logis, yang membutuhkan pekerja adalah pemilik gedung bukan gedung itu sendiri. Kalimat tersebut juga terjadi kesalahan pada kata butuh. Kata butuh tidak jelas menjadi bentuk kata kerja aktif atau kata kerja pasif. Agar menjadi kalimat yang efektif, kata butuh dapat diperbaiki dengan mengubahnya menjadi kata kerja aktif yaitu membutuhkan. Dengan menggunakan dasar tersebut, seharusnya kalimat (j) berbunyi Sejak proses pembangunannya saja, pemilik gedung-gedung itu membutuhkan pekerja yang tentunya didatangkan dari daerah lain.

Pada judul berita utama yang lain juga ditemukan ketidakefektifan kalimat pada ciri ketidaklogisan. Berikut berita utama tersebut.

k. Saat ini banyak sekali gedunggedung yang tumbuh di Surabaya.

(300RPMS.10/07/2017.Klgs)

Kalimat (k) tidak efektif dari segi kelogisan karena terdapat kata yang tidak logis. Pada kalimat tersebut, tumbuh memiliki arti bertambah besar. Kata tumbuh sering digunakan pada hal-hal berhubungan dengan makhluk hidup. Kata tumbuh tidak sesuai jika digunakan pada kata gedung-gedung. Kata yang sesuai adalah dibangun. Dengan menggunakan dasar tersebut, seharusnya kalimat (k) berbunyi Saat ini banyak gedung yang dibangun di Surabaya.

\section{B. Pembahasan}

Dalam penelitian ini terdapat ciri-ciri kalimat efektif. Menurut Arifin (2010), terdapat tujuh ciri-ciri dalam kalimat efektif di antaranya kesepadanan struktur, keparalelan bentuk, ketegasan makna, kehematan kata, kecermatan kata, kepaduan gagasan, dan kelogisan bahasa.

Penelitian ini mempunyai relevansi dengan penelitian sebelumnya yang mengangkat mengenai kalimat efektif. Beberapa di antaranya penelitian yang dilakukan oleh Alfian (2015), Setyawati (2014), dan Suti'ah (2015). Perbedaan ketiga penelitian yang terdahulu dengan penelitian ini terletak pada sumber data yang dikaji.

Penelitian ini ditemukan ciriciri kalimat efektif menurut teori Arifin meliputi (1) kesepadanan struktur; (2) keparalelan bentuk, (3) ketegasan makna; (4) kehematan kata; (5) kecermatan kata; (6) kepaduan gagasan, dan (7) kelogisan bahasa.

\section{SIMPULAN}

dan perdasarkan hasil penelitian dilakukan, dapat disimpulkan bahwa ditemukan ketidakefekttifan kalimat pada Rubrik Berita Utama Koran Harian Pagi Radar Surabaya Edisi Juli 2016. Dari segi ketidaksepadanan, disebabkan kalimat tidak memiliki subjek yang jelas dan terdapat konjungsi yang di depan predikat. Dari segi ketidakparalelan kalimat, disebabkan karena kata yang menduduki predikat memiliki bentuk berbeda dalam satu kalimat. Dari segi ketidaktegasan kalimat, disebabkan karena kata yang 
menjadi ide pokok kalimat tidak terletak di awal kalimat. Dari segi ketidakhematan kalimat, disebabkan beberapa kesalahan yaitu adanya pengulangan unsur kata yang sama, kesalahan pada bentuk jamak, terdapat kata sinonim dalam satu kalimat, terdapat pengulangan subjek, dan terdapat kata hiponim dalam satu kalimat. Dari segi ketidakcermatan kalimat, disebabkan karena pemilihan kata yang tidak tepat dan kesalahan kata baku. Dari segi ketidakpaduan kalimat, disebabkan karena penyisipan kata tentang antara predikat kata kerja dan objek. Serta dari segi ketidaklogisan kalimat, disebabkan karena terdapat kata yang tidak logis sehingga ide kalimat itu tidak dapat diterima oleh akal.

\section{SARAN}

Berdasarkan simpulan dari hasil penelitian dan pembahasan, disarankan sebagai berikut. Bagi penulis berita, harus lebih memperhatikan penulisan kalimat yang efektif dalam sebuah berita agar pembaca mampu menangkap isi informasi yang disampaikan dengan jelas. Bagi peneliti lain, hasil penelitian ini dapat dijadikan sumber ide untuk melakukan penelitian sejenis, tetapi memakai sumber data yang berbeda.

\section{DAFTAR PUSTAKA}

Arifin, Zaenal dan Tasai Amran. 2010. Cermat Berbahasa Indonesia untuk Perguruan Tinggi Edisi Revisi. Jakarta: Akademika Pressindo.

Chaer, Abdul. 2007. Linguistik Umum. Jakarta: Rineka Cipta.

Mahsun. 2005. Metode Penelitian Bahasa: Tahapan Strategi,
Metode, dan Tekniknya. Jakarta: PT RajaGrafindo Persada.

Moleong, Lexy J. 2014. Metodologi Penelitian Kualitatif Edisi Revisi. Bandung: PT Remaja Rosdakarya Offset.

Satata, Sri dan Devi Suswandari. 2012. Bahasa Indonesia. Jakarta: Penerbit Mitra Wacana Media.

Sutarman. 2009. Pengantar Teknologi Informasi. Jakarta: Bumi Aksara. 